\title{
Pengembangan Media Pembelajaran Buku Digital Interaktif Berbasis Pendekatan Matematika Realistik untuk Meningkatkan Kemampuan Spasial Siswa
}

\author{
Cici Puspaningrum ${ }^{1}$, Edi Syahputra ${ }^{2}$, Edy Surya ${ }^{2}$
}

\begin{abstract}
This study aims to: 1) develop an interactive digital book learning media based on a realistic mathematics learning approach on the valid, practical, and effective flat-sided geometry material (cubes and blocks) so as to improve students' mathematical spatial abilities; 2) improve students' mathematical spatial abilities by using interactive digital books based on a realistic mathematics learning approach on the flat side (cube and block) material. This research is a development research using the ADDIE model. The validity of the interactive digital book learning media assessed by the validators in terms of three aspects, namely the quality of content and objectives, learning/instructional strategies, and media design obtained a total average of 3.73 ("valid" category). The practicality of learning media is seen from the observation score of learning implementation in the first trial, which is 2.87 (category "poorly implemented") so that the second trial is carried out and a score of 3.73 is obtained (category "well implemented"). The effectiveness of learning media in terms of four aspects, namely classical completeness, student activity observation scores, observations of teachers' ability to manage learning, and student responses. The classical mastery of the students' mathematical spatial ability in the second trial was $86.67 \%$ (13 students). The average percentage of achievement of the ideal time of student activity in the second trial for three meetings was $22.2 \%, 26.87 \%, 26.87 \%, 13.9 \%, 7.87 \%$, and $2.32 \%$. The average score for observing the teacher's ability to manage learning in the second trial was 3.79 ("good" category). The average student response in the second trial was 3.74 ("interested" category). Based on the normalized gain index, it was found that in the second trial there was an increase in the value with a score of 0.40 ("medium" criteria).
\end{abstract}

Keywords: Interactive Digital Books, Realistic Mathematics Learning Approach, Spatial Ability, Development of Mathematics Learning Media, Cubes and Blocks.

\begin{abstract}
ABSTRAK
Penelitian ini bertujuan untuk: 1) mengembangkan media pembelajaran buku digital interaktif berbasis pendekatan pembelajaran matematika realistik pada materi bangun ruang sisi datar (kubus dan balok) yang valid, praktis, dan efektif sehingga dapat meningkatkan kemampuan spasial matematis siswa; 2) meningkatkan kemampuan spasial matematis siswa dengan menggunakan buku digital interaktif berbasis pendekatan pembelajaran matematika realistik pada materi bangun ruang sisi datar (kubus dan balok). Penelitian ini merupakan penelitian pengembangan dengan menggunakan model ADDIE. Kevalidan media pembelajaran buku digital interaktif yang dinilai oleh para validator ditinjau dari tiga aspek yaitu kualitias isi dan tujuan, strategi pembelajaran/instruksional, dan desain media memperoleh rata-rata total sebesar 3,73 (kategori "valid"). Kepraktisan media pembelajaran dilihat dari skor observasi keterlaksanaan pembelajaran pada uji coba I yaitu sebesar 2,87 (kategori "terlaksana dengan kurang baik") sehingga dilakukan uji coba II dan diperoleh skor sebesar 3,73 (kategori "terlaksana dengan baik"). Keefektifan media pembelajaran ditinjau dari empat aspek yaitu ketuntasan klasikal, skor observasi aktivitas siswa, observasi kemampuan guru mengelola pembelajaran, dan respon siswa. Ketuntasan klasikal kemampuan spasial matematis siswa pada uji coba II sebesar 86,67\% (13 siswa). Rata-rata persentase pencapaian waktu ideal aktivitas siswa pada uji coba II untuk tiga pertemuan adalah $22,2 \%, 26,87 \%, 26,87 \%, 13,9 \%, 7,87 \%$, dan $2,32 \%$. Rata- rata skor observasi kemampuan guru mengelola pembelajaran pada uji coba II adalah 3,79 (kategori "baik"). Rata-rata respon siswa pada uji coba II adalah 3,74 (kategori "tertarik). Berdasarkan indeks gain ternormalisasi, diperoleh bahwa pada uji coba II terjadi peningkatan nilai dengan skor 0,40 (kriteria "sedang").
\end{abstract}

Kata Kunci: Buku Digital Interaktif, Pendekatan Pembelajaran Matematika Realistik, Kemampuan Spasial, Pengembangan Media Pembelajaran Matematika, Kubus dan Balok.

\section{PENDAHULUAN}

Jhon Bird (Hidayat \& Fiantika, 2017: 386) menyatakan bahwa geometri merupakan salah satu

${ }^{1}$ Corresponding Author: Cici Puspaningrum

Program Magister Pendidikan Matematika Universitas Negeri Medan, Medan, 20221, Indonesia

E-mail: cicipuspaningrum@gmail.com

${ }^{2}$ Co-Author: Edi Syahputra \& Edy Surya

Program Studi Pendidikan Matematika, Universitas Negeri Medan, Medan, 20221, Indonesia bagian terpenting dari mata pelajaran matematika yang ada di kurikulum 2013. Hal ini sejalan dengan Asih (2018: 2) yang menyatakan bahwa geometri adalah salah satu cabang dari ilmu matematika yang harus dikuasai oleh siswa karena geometri mendukung banyak topik guna untuk memecahkan masalah dalam matematika yang akan bermanfaat dalam proses pemecahan masalah matematika. Kemampuan spasial sangat dibutuhkan dalam proses belajar mengajar guna untuk membantu anak dalam mengenali lingkungan

Pengembangan Media Pembelajaran Buku Digital Interaktif Berbasis Pendekatan Matematika Realistik untuk Meningkatkan Kemampuan Spasial Siswa 
yang ada disekitarnya. Boakes (Susanti \& Rosyidi, 2013) berpendapat bahwa visualisasi spasial merupakan bagian terpenting dalam pemikiran geometri, karena visualisasi merupakan kemampuan dalam membayangkan, merotasi, memilih atau membalikkan objek dua atau tiga dimensi. Namun pada kenyataannya kemampuan spasial yang dimiliki siswa masih rendah.

Hal ini terungkap melalui penelitian yang dilakukan oleh Wulansari dan Adirakasiwi (2019: 512) menyatakan bahwa siswa berkemampuan spasial rendah dalam menyelesaikan masalah matematika terhadap geometri bangun datar mengalami kesulitan untuk mencapai indikator kemampuan spasial matematis yang terdiri dari orientasi, visualisasi spasial, persepsi spasial, dan disembedding. Kemudian, pada penelitian Utami (2020: 131) menyatakan bahwa kemampuan spasial matematis siswa kelas $\mathrm{X}$ di salah satu Madrasah Aliyah Swasta di Singkawang masih rendah. Terdapat dua bentuk kesalahan dalam menyelesaikan soal kemampuan spasial matematis yaitu kesalahan konsep dan kesalahan operasi/prosedur. Beberapa temuan yang terjadi di atas, tidak jauh berbeda dengan kondisi yang terdapat pada SMP IT Ikhwanul Muslimin. Untuk melihat lebih lanjut permasalahan tersebut, peneliti melakukan perolehan tes awal tentang kemampuan spasial siswa SMP IT Ikhwanul Muslimin di kelas VIII-1 pada materi pokok bangun ruang sisi datar. Dari 26 siswa yang mengikuti tes, diperoleh sebanyak 5 orang siswa $(19,23 \%)$ yang tuntas dan 21 orang siswa $(80,97 \%)$ yang tidak tuntas. Dengan persentase masing-masing indicator dengan nilai persentase $59,29 \% \%$ rendah pada indikator relation, 65\% siswa sedang pada indikator visualization, $56,43 \%$ siswa rendah pada indikator perception, $47,14 \%$ siswa sangat rendah pada indikator mental rotation, dan $70 \%$ siswa sedang pada indikator orientation.

Oleh karena itu, diperlukan suatu kegiatan pembelajaran yang tepat untuk meningkatkan kemampuan spasial siswa, diantaranya dengan menggunakan media pembelajaran buku digital interaktif untuk dapat menggambarkan bangun-bangun geometri dalam konteks nyata. Sehingga siswa akan lebih mudah untuk memahaminya, bukan sekedar memahami persoalan-persoalan rutin saja. Demikian halnya disebutkan dalam penelitian Arifin, Pujiastuti, dan Sudiana (2020: 71) bahwa media pembelajaran dapat meningkatkan kemampuan spasial matematis yang disebabkan oleh beberapa hal, yaitu: (1) Dengan menggunakan media pembelajaran ini siswa dapat memanipulasi objek nyata yaitu memanipulasi objek yang bersifat fisik dan dapat menjadi pengalaman belajar bagi siswa; (2) Langkah-langkah pembelajaran yang terdapat pada buku panduan juga menggunakan pendekatan STEM sehingga pembelajaran dikaitkan antar setiap unsur STEM sehingga menjadi lebih bermakna; dan (3) Media pembelajaran yang dikembangkan dalam kegiatannya tidak menyediakan informasi mengenai materi secara langsung, melainkan menuntut siswa untuk mencari pengetahuan dengan cara mengeksplorasi media pembelajarannya dan membangun pengetahuan siswa secara mandiri. Penggunaan sumber belajar dan media pembelajaran merupakan suatu strategi dalam pembelajaran. Hal ini sejalan dengan penelitian Surya (2010) yang menyatakan bahwa pembelajaran matematika itu harus dibuat dengan strategi yang mengasyikkan dan menyenangkan agar tujuan pembelajaran dapat tercapai.

Hafizd dan Masriyah (2020: 135) bahwa media pembelajaran yang dikembangkan berkualitas baik karena memenuhi kriteria valid, praktis, dan efektif. Valid karena media pembelajaran dinyatakan valid oleh validator, praktis karena aktivitas guru menggunakan media pembelajaran dalam kelas sangat baik, dan aktivitas siswa dalam pembelajaran aktif, sedangkan efektif karena respon siswa terhadap pembelajaran positif, ketuntasan belajar siswa tercapai, serta adanya peningkatan pemahaman siswa. Dalam penelitian ini, peneliti menggunakan buku digital interaktif sebagai media pembelajaran untuk kegiatan belajar mengajar dengan alasan karena buku digital interaktif merupakan media pembelajaran yang mampu menyajikan pesan audiovisual secara jelas kepada peserta didik dan materi yang bersifat nyata, sehingga dapat diilustrasikan secara menarik kepada kepada peserta didik dengan penjelasan isi buku yang terdiri dari teks, gambar, video yang dapat merangsang minat dan motivasi belajar peserta didik untuk mencapai tujuan pembelajaran.

Adapun solusi lainnya agar kemampuan spasial siswa dapat meningkat yaitu dengan menggunakan pendekatan pembelajaran matematika realistik. Menurut Herzamzam dan Rahmad (2020: 185) pembelajaran matematika realistik pada dasarnya adalah pemanfaatan realitas dan lingkungan yang dipahami peserta didik untuk memperlancar proses pembelajaran matematika, sehingga mencapai tujuan pendidikan matematika secara lebih baik dari pada yang lalu. Tasmalina \& Prabowo (2018) yang menyatakan bahwa pendekatan matematika realistik memberikan kesempatan kepada siswa untuk lebih aktif dalam pemecahan masalah pembelajaran dan memiliki sikap positif terhadap mata pelajaran matematika. Dengan memecahkan masalah sendiri siswa akan membangun pengetahuannya sendiri dan mampu mengembangan kemampuannya dalam menghubungkan pengetahuannaya yang dia sudah punya dengan masalah yang diberikan sehingga kemampuan siswa lebih kompleks.

Berdasarkan uraian di atas, penulis tertarik untuk melakukan penelitian terkait dengan media pembelajaran, pendekatan pembelajaran matematika realistik, dan kemampuan spasial siswa yang berjudul "Pengembangan Media Pembelajaran Buku Digital Interaktif Berbasis Pendekatan Matematika Realistik untuk Meningkatkan Kemampuan Spasial Siswa di SMP IT Ikhwanul Muslimin". 


\section{KAJIAN TEORI \\ Media Pembelajaran}

Menurut Sudjana dalam (Netriwati dan Lena, 2017: 5) media merupakan sesuatu hal yang dapat dipergunakan antara pengirim pesan ke penerima sehingga dapat merangsang pikiran, perhatian, perasaan, dan minat peserta didik agar proses pembelajaran terjadi. Menurut Suparman dalam (Setiawan, 2017: 106) bahwa media adalah alat yang digunakan untuk menyalurkan pesan atau informasi dari pengirim kepada penerima pesan. Association for Education an Communication Technology (AECT) dalam (Asyhar, 2011: 4) memaknai media sebagai segala bentuk yang dimanfaatkan dalam proses penyaluran informasi. Dapat disimpulkan bahwa media adalah alat yang digunakan untuk menyampaikan pesan dan informasi sehingga dapat merangsang pikiran, perhatian, perasaan, dan minat seseorang. Wiarto (2016: 46) mengemukan bahwa media yang akan dipilih dalam proses pembelajaran juga harus memenuhi beberapa syarat, yaitu: (1) Visible; (2) Interesting; (3) Simple; (4) Useful; (5) Accurate; (6) Legitimate; (7) Structure (visuals).

Menurut Strauss dan Frost (dalam Indriana, 2011: 32) mengidentifikasikan sembilan faktor kunci yang harus menjadi pertimbangan dalam memilih media pengajaran. Kesembilan faktor kunci tersebut antara lain: (1) batasan sumber daya institusional, (2) kesesuaian media dengan mata pelajaran yang diajarkan; (3) karakteristik siswa atau anak didik, (4) perilaku pendidik dan tingkat keterampilannya; (5) sasaran mata pelajaran; (6) hubungan pembelajaran; (7) lokasi pembelajaran; (8) waktu pembelajaran; dan (9) tingkat keragaman media pembelajaran. Sedangkan menurut Sadjiman, Rahardjo, Haryono, dan Harjito (2011; 84) mengemukakan pemilihan media antara lain adalah: (1) bermaksud mendemonstrasikannya seperti halnya pada kuliah tentang media; (2) merasa sudah akrab dengan media tersebut, misalnya seorang dosen yang sudah terbiasa menggunakan proyektor transparansi; (3) ingin memberi gambarnya atau penjelasan yang lebih konkret; dan (4) merasa bahwa media dapat berbuat lebih dari yang biasa dilakukan, misalnya untuk menarik minat atau gairah belajar siswa. Pendapat-pendapat yang telah diuraikan di atas, dapat disimpulkan bahwa memilih media juga harus dengan banyak pertimbangan karena penggunaan media, diharapkan dapat memberikan hasil yang optimal, maka harus digunakan secara tepat. Adapun beberapa kriteria pemilihan media pembelajaran, yaitu: (1) media yang dipilih disukai oleh guru dan mampu untuk mengaplikasikannya; (2) media yang dipilih disesuaikan dengan ketersediaan sarana di sekolah; (3) dapat menunjang tercapainya tujuan pembelajaran; (4) disesuaikan dengan karakteristik siswa; (5) disesuaikan dengan materi pelajaran; (6) media yang dipilih harus menarik agar dapat merangsang siswa untuk belajar.

\section{Buku Digital}

Menurut Andina (2012: 81) bahwa buku digital yang dimaksud disini adalah publikasi berupa teks dan gambar dalam bentuk digital yang diproduksi, diterbitkan dan dapat dibaca dikomputer atau alat digital lainnya. Menurut Jannah, Fadiawati, dan Tania (2017: 186) bahwa buku digital merupakan buku elektronik dari sebuah buku tradisional dengan fitur digital yang dapat membantu pembaca dan merupakan alat yang menarik bagi kebanyakan peserta didik. Hal tersebut sejalan dengan pernyataan dari SEAMOLEC (2013:231) bahwa buku digital, atau disebut juga ebook merupakan sebuah publikasi yang terdiri dari teks, gambar, maupun suara dan dipublikasikan dalam bentuk digital yang dapat dibaca dikomputer maupun perangkat elektronik lainnya. Yusminar (2014: 34) menjelaskan kelebihan-kelebihan yang dimiliki oleh buku digital yang diantaranya yaitu: (1) Mudah dibawa karena berbentuk soft copy yang dapat digunakan pembaca dalam elektronik portable; (2) Tidak berat, digital book hanya perlu dimasukkan ke dalam folder di dalam elektronik portable, jadi yang dibawa hanya perangkat digital portable; (3) Mudah digandakan, digital book mudah untuk dicopy dengan gratis sehingga akan menghemat biaya dan akan mendukung kebutuhan belajar; (4) Hemat kertas, dalam era global warming berarti kita telah mendukung go green yang masih diusung pada masa kini.

Zambarbieri D \& Carniglia E. (Priyanto dan Sedyaningsih: 2013) juga menyebutkan bahwa dibandingkan dengan buku konvensional, buku digital dapat diperbarui dengan mudah, koreksi kesalahan dan penambahan informasi juga dapat terjadi dalam waktu yang lebih cepat dibandingkan dengan buku konvensional. Sedangkan kekurangan yang terdapat dalam buku digital interaktif adalah sebagai berikut: (1) Memerlukan alat khusus untuk membacanya seperti komputer, ebook reader, dan smartphone; (2) Membaca buku digital interaktif harus benar-benar dalam posisi menghadap komputer atau ebook reader, sehingga bagi orang yang tidak terbiasa menghadap layar terlalu lama akan merasa tidak nyaman; (3) Jika buku digital interaktif yang dikembangkan hanya berformat dalam satu jenis format, maka tidak dapat diakses pada semua jenis sistem operasi komputer; (4) Perlu waktu dalam menghidupkan komputer atau ebook reader dan perlu waktu pula untuk membuka buku digital Yusminar (2014: 35).

\section{Pendekatan Matematika Realistik}

Pendekatan matematika realistik awalnya dikembangkan dan diperkenalkan oleh Institut Freudhental di Belanda pada tahun 1970-an dengan nama realistic mathematics education. Pendekatan matematika realistik dilandasi oleh pemikiran Freudenthal bahwa matematika sebagai aktivitas manusia (human activity). Menurut Freudenthal (1991: 20) matematika harus dihubungkan dengan kenyataan (realitas), dekat dengan pengalaman anak-anak dan relevan bagi masyarakat agar matematika bernilai bagi manusia (human value). Kelas matematika bukan tempat memindahkan matematika dari guru kepada siswa, melainkan tempat siswa menemukan kembali ide dan konsep matematika melalui eksplorasi masalah-masalah nyata.

Pengembangan Media Pembelajaran Buku Digital Interaktif Berbasis Pendekatan Matematika Realistik untuk Meningkatkan Kemampuan Spasial Siswa 
Vol. 14, No. 2, Desember 2021

Freudhental (1991: 2) mengemukakan bahwa dalam proses pembelajaran realistik terdapat kegiatan mematematisasi. Dimana matematisasi adalah suatu proses untuk mematematikakan suatu fenomena, ilmu tidak lagi hanya sekedar kumpulan pengalaman tetapi melibatkan kegiatan mengorganisasi pengalaman dengan menggunakan matematika. Dalam penerapan pendekatan matematika realistik terdapat dua jenis matematisasi yaitu matematisasi horizontal dan matematisasi vertikal. Dalam matematisasi horizontal, siswa mencoba menyelesaikan soal-soal dari dunia nyata dengan cara mereka sendiri dan menggunakaan bahasa dan simbol mereka sendiri. Sedangkan matematisasi vertikal yaitu siswa mencoba menyusun prosedur umum yang dapat digunakan untuk menyelesaikan soal-soal sejenis secara langsung tanpa bantuan konteks. De Lange (1996) mefnjelaskan bahwa ada lima karakteristik dalam melakukan pembelajaran matematika realistik, diantaranya yaitu: (1) the use of real-life contexts; (2) the use of models; (3) student's free production; (4) interaction; dan (5) intertwining. Adapun langkah-langkah pembelajaran pada pendekatan matematika dalam penelitian ini disajikan pada tabel 1 berikut:

Tabel 1. Langkah-langkah Pendekatan Matematika Realistik

\begin{tabular}{|c|c|}
\hline Tahap & Perilaku Guru \\
\hline $\begin{array}{l}\text { Memahami } \\
\text { Masalah } \\
\text { Kontekstual }\end{array}$ & $\begin{array}{l}\text { Guru memberikan masalah } \\
\text { kontekstual dan menjelaskan soal } \\
\text { atau masalah dengan } \\
\text { memberikan petunjuk/saran } \\
\text { seperlunya (terbatas) terhadap } \\
\text { bagian-bagian tertentu yang } \\
\text { dipahami siswa. }\end{array}$ \\
\hline $\begin{array}{l}\text { Menyelesaikan } \\
\text { Masalah } \\
\text { Kontekstual }\end{array}$ & $\begin{array}{l}\text { Guru memotivasi siswa untuk } \\
\text { menyelesaikan masalah tersebut } \\
\text { dengan memberikan pertanyaan- } \\
\text { pertanyaan penuntun untuk } \\
\text { mengarahkan siswa memperoleh } \\
\text { penyelesaian soal. }\end{array}$ \\
\hline $\begin{array}{l}\text { Membandingkan } \\
\text { dan } \\
\text { Mendiskusikan } \\
\text { Jawaban }\end{array}$ & $\begin{array}{l}\text { Guru mengarahkan siswa untuk } \\
\text { membandingkan hasil diskusi } \\
\text { mereka masing-masing di depan } \\
\text { kelas. }\end{array}$ \\
\hline $\begin{array}{l}\text { Menarik } \\
\text { Kesimpulan }\end{array}$ & $\begin{array}{l}\text { Guru mengarahkan siswa untuk } \\
\text { menarik kesimpulan tentang } \\
\text { konsep, definisi, teorema, prinsip } \\
\text { atau prosedur matematika yang } \\
\text { terkait dengan masalah } \\
\text { kontekstual yang baru } \\
\text { diselesaikan. }\end{array}$ \\
\hline
\end{tabular}

\section{Kemampuan Spasial}

Shoimin (2016: 150)

Masykur dan Fathani (2017: 108) kemampuan spasial dicirikan oleh hal-hal seperti: (1) Memberikan gambaran visual yang jelas ketika menjelaskan sesuatu; (2) Mudah membaca peta atau diagram; (3) Menggambar sosok orang atau benda mirip dengan aslinya; (4) Sangat menikmati kegiatan visual, seperti teka-teki atau sejenisnya; (5) Mencoret-coret di atas kertas atau buku tugas sekolah; dan (6) Lebih memahami informasi lewat gambar daripada kata-kata atau uraian. Maier (1998) membagi kemampuan spasial menjadi lima aspek yaitu: (1) Spasial Visualization; (2) Spatial Perception; (3) Spatial Relation; (4) Spatial Orientation; (5) Mental Rotation. Dari lima aspek yang telah dikemukakan oleh Maier, maka dapat dirancang suatu indikator dari kemampuan spasial yang dijelaskan pada tabel 2 berikut ini:

Tabel 2. Kisi-kisi Tes Kemampuan Spasial

$$
\text { Aspek }
$$

Kemampuan

Indikator

Spasial

\begin{tabular}{ll}
\hline \multirow{3}{*}{ Orientation } & $\begin{array}{l}\text { Dapat menyebutkan karakteristik } \\
\text { bangun ruang secara umum dengan } \\
\text { membayangkan perubahan dari } \\
\text { perspektif yang diberikan. }\end{array}$ \\
\hline \multirow{3}{*}{$\begin{array}{l}\text { Dental } \\
\text { Rotation }\end{array}$} & $\begin{array}{l}\text { suatu bangun ruang (kubus dan } \\
\text { balok) sebagai akibat dari rotasi atau } \\
\text { ditranslasikan dengan cara } \\
\text { membayangkannya. }\end{array}$ \\
\hline \multirow{3}{*}{ Visualization } & $\begin{array}{l}\text { Dapat menyatakan kondisi yang } \\
\text { sebenarnya dari suatu stimulus objek } \\
\text { bangun ruang melalui pembayangan. }\end{array}$ \\
\hline & $\begin{array}{l}\text { Dapat menyatakan kondisi (bentuk) } \\
\text { yang sebenarnya dari suatu tampilan } \\
\text { (stimulus) 3D yang didasarkan pada } \\
\text { apa yang dirasakan. }\end{array}$ \\
\hline \multirow{2}{*}{ Relation } & $\begin{array}{l}\text { Dapat menyatakan hubungan unsur- } \\
\text { unsur dalam 3D (hubungan garis, } \\
\text { bidang, dan titik) dari stimulus yang } \\
\text { ditampilkan. }\end{array}$ \\
\hline
\end{tabular}

\section{METODE PENELITIAN}

Penelitian ini dilaksanakan di SMP IT Ikhwanul Muslimin Medan pada semester genap tahun ajaran 2020/2021. Subjek dalam penelitian ini adalah siswa kelas VIII-1 dan VIII-2 SMP IT Ikhwanul Muslimin Medan. Objek dalam penelitian ini adalah media pembelajaran buku digital interaktif berbasis pendekatan matematika realistik pada materi bangun ruang sisi datar (kubus dan balok). Jenis penelitian ini adalah Penelitian Pengembangan (Research and Development) dengan menggunakan model ADDIE.

\section{Teknik Analisis Data}

Teknik analisis berikut ini berlaku untuk menganalisis kevalidan dari media pembelajaran buku digital interaktif (Nasrah, Jasrudin dan Tawil,

2015: 241): $V_{a}=\frac{\sum_{i=1}^{n} A_{i}}{n}$

Keterangan:

$V_{a}=$ nilai rata-rata total untuk semua aspek.

$A_{i}=$ rata-rata nilai untuk aspek ke-i.

$n=$ banyaknya aspek.

Tabel 3. Kriteria Kevalidan Media Pembelajaran

\begin{tabular}{cc}
\hline Rentang Skor & Kriteria \\
\hline $1 \leq \mathrm{Va}<2$ & Tidak Valid \\
\hline $2 \leq \mathrm{Va}<3$ & Kurang Valid \\
\hline $3 \leq \mathrm{Va}<4$ & Valid \\
\hline $\mathrm{Va}=4$ & Sangat Valid \\
\hline
\end{tabular}

Pengembangan Media Pembelajaran Buku Digital Interaktif Berbasis Pendekatan Matematika Realistik untuk Meningkatkan Kemampuan Spasial Siswa 
Vol. 14, No. 2, Desember 2021

Menentukan rata-rata skor observasi keterlaksanaan pembelajaran:

$$
O_{k}=\frac{\sum_{j=1}^{m} P_{i}}{m}
$$

Keterangan:

$O_{k}=$ rata-rata skor observasi keterlaksanaan pembelajaran

$P_{i}=$ rata-rata skor observasi keterlaksanaan pembelajaran tiap pertemuan

$m$ = banyaknya pertemuan

Tabel 4. Kriteria Tingkat Keterlaksanaan Pembelajaran

\begin{tabular}{cc}
\hline $\begin{array}{c}\text { Tingkat Keterlaksanaan } \\
\text { Pembelajaran }\end{array}$ & $\begin{array}{c}\text { Kriteria } \\
\text { Keterlaksanaan }\end{array}$ \\
\hline $1 \leq O_{k}<2$ & Tidak terlaksana \\
\hline $2 \leq O_{k}<3$ & $\begin{array}{c}\text { Terlaksana dengan } \\
\text { kurang baik }\end{array}$ \\
\hline $3 \leq O_{k}<4$ & $\begin{array}{c}\text { Terlaksana dengan } \\
\text { baik }\end{array}$ \\
\hline$O_{k}=4$ & $\begin{array}{c}\text { Terlaksana dengan } \\
\text { sangat baik }\end{array}$ \\
\hline
\end{tabular}

Setelah dilakukan tes, nilai kemampuan spasial matematis siswa dihitung dengan rumus berikut:

$$
K S M=\frac{S_{s}}{S_{t}} \times 100
$$

Sumber: (Al-Tabany, $2017: 241$ )

Keterangan:

$$
\begin{array}{ll}
K S M & =\text { Kemampuan spasial matematis siswa } \\
S_{S} & =\text { Jumlah skor yang diperoleh siswa } \\
S_{t} & =\text { Jumlah skor total }
\end{array}
$$

Tabel 5. Kategori Tingkat Kemampuan Spasial Matematis

\begin{tabular}{cc}
\hline Jangkauan & Nilai Kualitatif \\
\hline $90 \leq \mathrm{KSM} \leq 100$ & Sangat Tinggi \\
\hline $80 \leq \mathrm{KSM}<90$ & Tinggi \\
\hline $70 \leq \mathrm{KSM}<80$ & Cukup \\
\hline $60 \leq \mathrm{KSM}<70$ & Rendah \\
\hline $0 \leq \mathrm{KSM}<60$ & Sangat Rendah \\
\hline
\end{tabular}

Data hasil pengamatan aktivitas siswa selama kegiatan pembelajaran dianalisis berdasarkan persentase. Persentase aktivitas siswa yaitu frekuensi setiap aspek pengamatan dibagi dengan jumlah frekuensi semua aspek pengamatan dikali $100 \%$ atau,

Persentase waktu ideal $=\frac{\text { Frekuensi setiap aspek pengamatan }}{\text { Jumlah frekuensi semua aspek pengamatan }} \times 100 \%$

Tabel 6. Kriteria Pencapaian Waktu Ideal Aktivitas

Siswa

\begin{tabular}{lll}
\hline Aspek Pengamatan & \multicolumn{1}{c}{ Persentase Efektif (P) } \\
\cline { 2 - 3 } $\begin{array}{l}\text { Memperhatikan dan } \\
\text { mendengarkan } \\
\text { penjelasan guru atau } \\
\text { teman }\end{array}$ & WT $20 \%$ dari & $15 \% \leq$ PWI $\leq 25 \%$ \\
\hline $\begin{array}{l}\text { Membaca dan } \\
\text { memahami masalah } \\
\text { pada media }\end{array}$ & \begin{tabular}{l}
$30 \%$ dari $\quad 25 \% \leq$ PWI $\leq 35 \%$ \\
\hline
\end{tabular} &
\end{tabular}

pembelajaran atau

LKPD

Menemukan

penyelesaian dan

menyelesaikan

masalah yang

\begin{tabular}{|c|c|c|}
\hline $\begin{array}{l}\text { Menarik kesimpulan } \\
\text { dari materi yang } \\
\text { dipelajari }\end{array}$ & $\begin{array}{l}10 \% \\
\text { WT }\end{array}$ & dari $_{5 \%} \leq \mathrm{PWI} \leq 15 \%$ \\
\hline $\begin{array}{l}\text { Melakukan kegiatan } \\
\text { yang tidak relevan } \\
\text { dengan pembelajaran }\end{array}$ & 0 & $0 \% \leq \mathrm{PWI} \leq 15 \%$ \\
\hline
\end{tabular}

$30 \%$
WT $\quad$ dari $_{25 \%} \leq$ PWI $\leq 35 \%$

diberikan

\begin{tabular}{llr}
\hline Berdiskusi dan & $10 \%$ \\
bertanya kepada guru & dari & \\
WT &
\end{tabular} PWI $\leq 15 \%$

atau teman

dengan pembelajaran

Sumber: (Sinaga, 2015)

Keterangan:

PWI = persentase waktu ideal

WT = waktu tersedia pada tiap pertemuan

Menentukan rata-rata skor respon siswa:

$$
R_{s}=\frac{\sum_{j=1}^{m} s_{i}}{m}(\text { adaptasi Sinaga, 2015) }
$$

Keterangan:

$R_{s}=$ rata-rata respon siswa

$S_{i}=$ rata-rata skor respon tiap siswa

$m$ = banyaknya siswa

Tabel 7. Kriteria Tingkat Siswa

\begin{tabular}{cl}
\hline Tingkat Respon Siswa & Kriteria Respon \\
\hline $1 \leq R_{S}<2$ & Tidak Tertarik \\
\hline $2 \leq R_{S}<3$ & Kurang Tertarik \\
\hline $3 \leq R_{S}<4$ & Tertarik \\
\hline$R_{S}=4$ & Sangat Tertarik \\
\hline
\end{tabular}

Data yang diperoleh dari hasil tes kemampuan spasial dianalisis untuk mengetahui peningkatan kemampuan spasial siswa. Data diperoleh dari hasil pre-test dan post-test kemampuan spasial siswa. Untuk menghitung peningkatan kemampuan spasial siswa, maka terlebih dahulu ditentukan nilai n-gainnya. Dalam menghitung $n$-gain digunakan rumus yaitu (Lestari dan Yudhanegara, 2015: 235):

Keterangan:

$$
\text { Normalized gain }=\frac{S_{\text {post }}-S_{\text {pre }}}{S_{\text {max }}-S_{\text {pre }}}
$$

$N-$ Gain $=$ skor gain ternormalisasi

$S_{\text {post }}=$ skor tes akhir

$S_{\text {pre }} \quad=$ skor tes awal

$S_{\max }=$ skor maksimum

Tabel 8. Kriteria Skor N-Gain

\begin{tabular}{cc}
\hline Skor Gain $(\mathbf{g})$ & Kriteria \\
\hline $\mathrm{g} \leq 0,3$ & Rendah \\
\hline $0,3<\mathrm{g} \leq 0,7$ & Sedang \\
\hline $\mathrm{g}>0,7$ & Tinggi \\
\hline & Sumber: $($ Hake, 1999$)$
\end{tabular}

Pengembangan Media Pembelajaran Buku Digital Interaktif Berbasis Pendekatan Matematika Realistik untuk Meningkatkan Kemampuan Spasial Siswa 


\section{HASIL PENELITIAN \\ Kevalidan Media Pembelajaran Buku Digital Interaktif}

Tabel 9. Rangkuman Hasil Validasi Media

Pembelajaran Interaktif dan Instrumen Pembelajaran yang divalidasi

\begin{tabular}{lrcc}
\hline \multicolumn{2}{c}{ Instrumen yang Divalidasi } & Skor & Kategori \\
\hline Media pembelajaran & 3,73 & Valid \\
\hline Rencana pembelajaran (RPP) & 3,74 & Valid \\
\hline Lembar kerja peserta didik (LKPD) & 3,84 & Valid \\
\hline $\begin{array}{l}\text { Tes awal kemampuan } \\
\text { matematis }\end{array}$ & spasial & 3,85 & Valid \\
$\begin{array}{l}\text { Tes akhir kemampuan } \\
\text { matematis }\end{array}$ & spasial 3,89 & Valid \\
\hline
\end{tabular}

\section{Kepraktisan Media Pembelajaran Buku Digital Interaktif}

Kepraktisan pengembangan media pembelajaran buku digitial interaktif telah memenuhi kriteria praktis ditinjau dari hasil penilaian dari para ahli (validator), semua validator menyatakan bahwa media pembelajaran buku digital interaktif yang dikembangkan layak digunakan dengan sedikit revisi. Kemudian, observasi keterlaksanaan pembelajaran dengan menggunakan media pembelajaran buku digital interaktif pada tabel 10 berikut:

Tabel 10. Rangkuman Hasil Observasi Keterlaksanaan Pembelajaran

\begin{tabular}{|c|c|c|c|c|c|}
\hline & \multicolumn{2}{|c|}{ Uji Coba I } & \multicolumn{3}{|c|}{ Uji Coba II } \\
\hline & PI & PII & PI & PII & PIII \\
\hline Skor & 2,80 & 2,93 & 3,60 & 3,73 & 3,87 \\
\hline Rata-rata & \multicolumn{2}{|c|}{2,87} & \multicolumn{3}{|c|}{3,73} \\
\hline Kategori & \multicolumn{2}{|c|}{$\begin{array}{c}\text { Terlaksana } \\
\text { dengan Kurang } \\
\text { Baik }\end{array}$} & \multicolumn{3}{|c|}{$\begin{array}{c}\text { Terlaksana dengan } \\
\text { Baik }\end{array}$} \\
\hline
\end{tabular}

Berdasarkan tabel tersebut dapat diketahui bahwa skor observasi keterlaksanaan pembelajaran belum memenuhi kriteria kepraktisan pada uji coba I yaitu dengan skor 2,80 pada pertemuan I, skor 2,93 pada pertemuan II, dan rata- rata 2,87 (kategori "Terlaksana dengan Kurang Baik"). Sedangkan pada uji coba II diperoleh skor 3,60 pada pertemuan I, 3,73 pada pertemuan II, dan 3,87 pada pertemuan III. Rata-rata hasil observasi keterlaksanaan pembelajaran pada uji coba II adalah 3,73 dengan kategori "Terlaksana dengan Baik".

\section{Keefektifan Media Pembelajaran Buku Digital Interaktif}

\section{Ketercapaian Tes Kemampuan Spasial Matematis}

Berdasarkan hasil analisis tes pada uji coba I dan II diperoleh bahwa kemampuan spasial siswa telah memenuhi kriteria ketuntasan secara klasikal. Deskripsi hasil kemampuan spasial siswa ditunjukkan pada tabel 11 berikut:
Tabel 11. Rangkuman Ketercapaian Tes Kemampuan

Spasial Matematis

\begin{tabular}{ccc}
\hline \multirow{2}{*}{ Uji Coba } & \multicolumn{2}{c}{ Ketercapaian pada } \\
\cline { 2 - 3 } & Tes awal & Tes Akhir \\
\hline I & $20 \%$ & $40 \%$ \\
\hline II & $33,33 \%$ & $86,67 \%$ \\
\hline
\end{tabular}

Ketercapaian tes akhir kemampuan spasial matematis siswa pada uji coba I adalah sebesar $40 \%$ dengan jumlah siswa sebanyak 6 orang dinyatakan tuntas. Jadi, dapat disimpulkan bahwa pada uji coba I penerapan media pembelajaran buku digital interaktif yang dikembangkan belum memenuhi kriteria pencapaian ketuntasan secara klasikal $(>80 \%)$. Namun, pada uji coba II ketercapaian tes akhir kemampuan spasial matematis siswa telah memenuhi kriteria yang ditentukan yaitu sebesar $86,67 \%$ dengan jumlah siswa sebanyak 13 orang dinyatakan tuntas. Sehingga, dapat dikatakan bahwa media pembelajaran buku digital interaktif telah memenuhi kriteria keefektifan pada aspek ketercapaian kemampuan spasial matematis siswa.

\section{Aktivitas siswa}

Tabel 12. Hasil Analisis Persentase Pencapaian Waktu Ideal Aktivitas Siswa pada Uji Coba I

Persentase Pencapaian Waktu Ideal Aktivitas Pertemuan Siswa tiap Aspek Pengamatan (\%)

\begin{tabular}{ccccccc} 
& 1 & 2 & 3 & 4 & 5 & 6 \\
\hline I & 25 & 29,2 & 26,4 & 8.33 & 5,56 & 5,56 \\
\hline II & 23,6 & 29,2 & 25 & 12,5 & 6,94 & 1,39 \\
\hline $\begin{array}{c}\text { Rata-rata } \\
\text { Persentase }\end{array}$ & 24,3 & 29,2 & 25,7 & 10,42 & 6,25 & 3,48 \\
\hline
\end{tabular}

Berdasarkan hasil analisis pada di atas, rata-rata persentase pencapaian waktu ideal aktivitas siswa untuk dua pertemuan pada uji coba I adalah $24,3 \%$, $29,2 \%, \quad 25,7 \%, \quad 10,42 \%, 6,25 \%$, dan $3,48 \%$. Selanjutnya, hasil pencapaian waktu yang diperoleh dirujuk pada kriteria keberhasilan yang telah ditetapkan sebelumnya. Dari hasil di atas, dapat disimpulkan bahwa aktivitas siswa telah mencapai persentase pencapaian waktu ideal dimana dari keenam aspek yang diobservasi, persentasi aktivitas siswa masih berada pada interval toleransi persentase pencapaian waktu ideal yang ditetapkan.

Berdasarkan hasil analisis tentang persentase pencapaian waktu ideal aktivitas siswa pada uji coba II yang disajikan pada tabel 13 , diperoleh data rata-rata persentase pencapaian waktu ideal aktivitas siswa untuk tiga pertemuan pada uji coba II adalah $22,2 \%$, $26,87 \%$, 26,87\%, $13,9 \%, \quad 7,87 \%$, dan $2,32 \%$. Selanjutnya, hasil pencapaian waktu yang diperoleh dirujuk pada kriteria keberhasilan yang telah ditetapkan sebelumnya. Dari hasil di atas, dapat disimpulkan bahwa aktivitas siswa telah mencapai persentase pencapaian waktu ideal. 
Vol. 14, No. 2, Desember 2021

Tabel 13. Hasil Analisis Persentase Pencapaian Waktu Ideal Aktivitas Siswa Pada Uji Coba II

Persentase Pencapaian Waktu Ideal Aktivitas Pertemuan Siswa tiap Aspek Pengamatan (\%)

\begin{tabular}{ccccccc}
\cline { 2 - 7 } & 1 & 2 & 3 & 4 & 5 & 6 \\
\hline I & 20,8 & 27,8 & 25 & 15.3 & 8.33 & 2,78 \\
\hline II & 23,6 & 26.4 & 27,8 & 12,5 & 6,94 & 2,78 \\
\hline III & 22,2 & 26,4 & 27,8 & 13,9 & 8,33 & 1,39 \\
\hline $\begin{array}{c}\text { Rata-rata } \\
\text { Persentase }\end{array}$ & 22,2 & 26,87 & 26,87 & 13,9 & 7,87 & 2,32 \\
\hline
\end{tabular}

\section{Respon Siswa}

Berdasarkan analisis hasil respon siswa, diperoleh bahwa pada uji coba I dan uji coba II, siswa merasa tertarik dengan media pembelajaran yang dikembangkan. Secara lebih jelas, data ditampilkan pada Tabel 14 berikut ini:

Tabel 14. Rangkuman Hasil Analisis Angket Respon Siswa

\begin{tabular}{ccccc}
\hline Responden & \multicolumn{2}{c}{ Uji Coba I } & \multicolumn{2}{c}{ Uji Coba II } \\
\cline { 2 - 5 } & Skor & Kategori & Skor & Kategori \\
\hline Siswa & 3,70 & Tertarik & 3,74 & Tertarik \\
\hline
\end{tabular}

Hal ini terlihat dari skor rata-rata respon siswa menunjukkan ketertarikan terhadap pembelajaran dengan media pembelajaran yang dikembangkan. Dilihat dari skor angket respon siswa pada uji coba I sebesar 3,70 dengan kategori terarik dan pada uji coba II sebesar 3,74 dengan kategori terarik. Sehingga dapat disimpulkan bahwa dari respon siswa terhadap media pembelajaran buku digital interaktif yang dikembangkan efektif.

\section{Peningkatan Kemampuan Spasial}

Berdasarkan hasil analisis tes kemampuan spasial matematis siswa pada uji coba I dan uji coba II menunjukkan bahwa terdapat peningkatan kemampuan spasial matematis siswa. Adapun skor peningkatan kemampuan spasial matematis siswa pada uji coba I dan uji coba II dapat dilihat pada tabel 15 berikut ini:

Tabel 15. Peningkatan Kemampuan Spasial Matematis Siswa

\begin{tabular}{cccc}
\hline \multicolumn{2}{c}{ Uji Coba I } & \multicolumn{2}{c}{ Uji Coba II } \\
\hline Skor & Kategori & Skor & Kategori \\
\hline 0,20 & Rendah & 0,40 & Sedang
\end{tabular}

Berdasarkan rata-rata gain ternormalisasi, diperoleh bahwa pada uji coba I terjadi peningkatan kemampuan spasial siswa dengan kriteria rendah dengan skor 0,20 $(N$-Gain $\leq 0,3)$ dan pada uji coba II terjadi peningkatan nilai dengan kriteria sedang dengan skor $0,40 \quad(0,3<N$-Gain $\leq 0,7)$. Sehingga dapat disimpulkan bahwa media pembelajaran buku digital interakitf yang dikembangkan ini dapat meningkatkan kemampuan spasial matematis siswa.

\section{PEMBAHASAN}

Berdasarkan hasil validasi dari media pembelajaran buku digital interaktif yang dilakukan oleh ahli media, maka media pembelajaran buku digital interaktif yang dikembangkan memenuhi tuntutan kebutuhan pembelajaran untuk materi pokok bangun ruang sisi datar (kubus dan balok). Hal ini didukung oleh pendapat Rozak, Darmadi, dan Murtafi'ah (2018: 40) bahwa media pembelajaran memenuhi kriteria kevalidan apabila dikatakan valid oleh validator. Selain itu, Arsyad (2017: 75) yang mengatakan bahwa salah satu kriteria media yang layak dipilih adalah media yang selaras dan sesuai dengan kebutuhan tugas pembelajaran. Pendapat ini juga didukung oleh Sutikno (2013: 112) yang mengatakan bahwa media layak digunakan jika mendukung isi materi pembelajaran. Hal yang serupa juga diungkapkan dalam penelitian Marselina \& Muhtadi (2019: 204) yang mengatakan bahwa media pembelajaran yang dikembangkan berkualitas dan layak digunakan jika memenuhi validitas isi dan konstruk yang dinilai oleh validator. Sehingga dapat disimpulkan bahwa media pembelajaran buku digital interaktif yang dikembangkan sudah memenuhi indikator kevalidan.

Kepraktisan pengembangan media pembelajaran buku digitial interaktif telah memenuhi kriteria praktis ditinjau dari hasil penilaian dari para ahli (validator), semua validator menyatakan bahwa media pembelajaran buku digital interaktif yang dikembangkan layak digunakan dengan sedikit revisi. Hal ini didukung oleh pendapat Akker (2007: 66) yang menyatakan bahwa kriteria kepraktisan media pembelajaran dikatakan praktis apabaila validator menilai bahwa apa yang dikembangkan dapat dierapkan. Sejalan dengan penelitian Annisa, Putra, dan Dharmono (2020: 78) yang menyatakan bahwa kepraktisan media pembelajaran penting untuk diketahui karena salah satu syarat media pembelajaran adalah mudah untuk digunakan oleh pengguna.

Berdasarkan skor observasi keterlaksanaan pembelajaran belum memenuhi kriteria kepraktisan pada uji coba I. Sedangkan pada uji coba II telah memenuhi kriteria kepraktisan dengan rata-rata hasil observasi keterlaksanaan pembelajaran pada uji coba II adalah 3,73 dengan kategori "Terlaksana dengan Baik". Hal ini didukung oleh pendapat Akker (2007: 66) yang menyatakan bahwa kriteria kepraktisan media pembelajaran dikatakan praktis apabaila hasil pengamatan media pembelajaran di kelas termasuk dalam kategori baik atau sangat baik. Dalam penelitian Marselina \& Muhtadi (2019: 206) bahwa media pembelajaran buku digital mudah digunakan dan efektif untuk meningkatkan hasil belajar siswa. Maka dari itu, dapat disimpulkan bahwa buku digital interaktif yang dikembangkan sudah memenuhi indikator kepraktisan.

Hasratuddin (2018: 242) menyatakan bahwa indikator keefektifan pembelajaran didasarkan pada pencapaian ketuntasan belajar apabila lebih dari $80 \%$ siswa telah tuntas, waktu yang digunakan dalam pembelajaran efisien atau tidak melebihi pembelajaran

Pengembangan Media Pembelajaran Buku Digital Interaktif Berbasis Pendekatan Matematika Realistik untuk Meningkatkan Kemampuan Spasial Siswa 
biasa, serta respon siswa terhadap pembelajaran positif. Hal ini didukung oleh penelitian Sonda, Alimuddin, dan Asdar (2016) yang menyatakan kriteria keefektifan pembelajaran ditinjau dari skor $\mathrm{N}$-gain berada pada kategori sedang dan ketuntasan siswa secara klasikal lebih dari $80 \%$. Sejalan dengan penelitian Marselina dan Muhtadi (2019) membuktikan bahwa dengan belajar menggunakan digital interaktif efektif untuk meningkatkan hasil belajar siswa. Ketuntasan belajar siswa disebabkan karena ide penting yang diambil dari teori Vygotsky adalah scaffolding yang sejalan dengan salah satu karakteristik dari pembelajaran pendekatan matematika realistik yaitu menekankan perlunya interaksi yang terus menerus antara siswa yang satu dengan siswa yang lain, juga antar siswa dengan pembimbing (guru), dan siswa dengan perangkat pembelajaran sehingga setiap siswa mendapatkan manfaat positif dari interaksi tersebut. Selain itu dalam pendekatan matematika realistik bantuan yang diberikan guru hanya sebatas pada pertanyaanpertanyaan siswa di awal pemecahan masalah kontekstual yang diberikan pembimbing (guru) dengan memberikan petunjuk atau saran sampai siswa mengerti dengan maksud soal.

Adapun pada penelitian Rosida, Faidawati, dan Jalmo (2017: 40) yang menyatakan bahwa daya tarik penggunaan e-book interaktif dapat meningkatkan aktivitas siswa untuk terlibat aktif dalam pembelajaran. Selain itu, hasil penelitian Wibowo (2014:101) yang menyatakan bahwa aktivitas siswa berkaitan dengan penggunaan multimedia book tergolong sangat tinggi. Meningkatnya aktivitas siswa pada saat pembelajaran sejalan dengan teori belajar bermakna Ausubel yang juga sesuai dengan pendekatan matematika realistik yaitu menggunakan masalah kontekstual yang berfungsi sebagai motivasi awal atau "starting point" dalam pembelajaran, guru meminta kepada siswa untuk menggunakan strategi atau cara mereka sendiri dalam memecahkan soal yang berbentuk soal komunikasi matematika. Untuk keperluan tersebut, siswa harus mampu menghubungkan pengetahuan yang dimiliki dengan permasalahan yang dihadapi. Bila pengetahuan/konsep yang dimiliki siswa belum dapat digunakan dalam memecahkan masalah komunikasi matematika, maka guru perlu membimbing siswa (bersifat terbatas) dalam menemukan konsep tersebut. Dengan demikian, siswa akan mampu menyelesaikan masalah kontekstual yang diajukan kepadanya apabila ia memiliki cukup pengetahuan yang terkait dengan masalah tersebut.

Hal ini juga sejalan dengan teori Piaget yang menganggap bahwa matematika tidak diterima secara pasif, matematika dibentuk dan ditemukan oleh siswa secara aktif. Piaget juga beranggapan bahwa proses pembelajaran adalah proses aktif karena pengetahuan terbentuk dari dalam subjek belajar sehingga perlu diciptakan suasana yang memungkinkan terjadinya interaksi di antara subjek belajar (Sumarli, Nugroho, dan, Yulianti, 2018: 68). Berdasarkan teori Piaget, pendekatan matematika realistik dalam kegiatan pembelajaran memfokuskan pada proses berfikir siswa, bukan sekedar pada hasil. Selain itu, dalam pembelajaran pendekatan matematika realistik mengutamakan siswa berinisiatif untuk menemukan jawaban dari soal kontekstual yang diberikan guru dengan caranya sendiri dan siswa didorong untuk terlibat aktif dalam kegiatan pembelajaran untuk mengonstruksi atau menemukan konsep. Berdasarkan hasil penelitian, teori belajar yang mendukung, dan hasil penelitian terdahulu di atas, dapat disimpulkan bahwa media pembelajaran buku digital interaktif yang dikembangkan telah memenuhi indikator keefektifan ditinjau dari observasi aktivitas siswa.

Menurut Arsyad (2017: 25) pembelajaran dengan menggunakan media pembelajaran dianggap sebagai penarik perhatian dan membuat siswa tetap terjaa dan memperhatikan. Dengan kata lain, media pembelajaran mampu membuat kegiatan belajar mengajar di kelas menjadi efektif. Berdasarkan penelitian Anggraini (2020: 44) bahwa untuk mendukung efektivitas media pembelajaran e-book Novelmatika bahwa respon siswa terhadap pembelajaran matematika dengan menggunakan e-book Novelmatika adalah seluruh siswa (100\%) setuju bahwa proses belajar menggunakan e-book Novelmatika menarik dan mengasyikkan, serta materi ebook Novelmatika menyenangkan bagi mereka. Tingginya respon siswa yang positif juga didukung oleh teori belajar Brunner bahwa belajar matematika adalah belajar tentang konsep-konsep dan struktur-struktur matematika yang terdapat dalam materi yang dipelajari serta mencari hubungan-hubungan antara konsep-konsep dan struktur-struktur matematika. Pemahaman terhadap konsep dan struktur suatu materi menjadikan materi itu dipahami secara lebih komprehensif. Selain dari itu, pengetahuan siswa lebih mudah diingat dan bertahan lama apabila yang dipelajari dengan pola yang terstruktur. Berdasarkan teori Brunner, pendekatan matematika realistik sesuai dalam kegiatan pembelajaran karena di awal pembelajaran sangat dimungkinkan siswa memanipulasi objek-objek yang ada kaitannya dengan masalah kontekstual yang diberikan guru secara langsung. Kemudian pada proses matematisasi vertikal, siswa memanipulasi simbolsimbol.

Berdasarkan hasil penelitian Azriati, Syahputra, dan Sumarno (2018: 2) mengatakan bahwa penggunaan media pembelajaran dalam proses belajar mengajar dapat meningkatkan kemampuan matematika, salah satunya yaitu kemampuan spasial siswa. Hal tersebut juga dikemukakan dalam penelitian Uygan dan Kurtulus (2016) yang menyatakan bahwa pembelajaran dengan bantuan media yang tepat berpengaruh terhadap peningkatan kemampuan spasial siswa. Selain itu, dalam penelitian Istifarida, Santoso, dan Yusup (2017: 143) menyatakan bahwa terdapat peningkatan yang signifikan terhadap kecakapan berfikir keruangan setelah penggunaan e-book berbasis PBL-GIS. Berdasarkan hasil penelitian yang telah dilakukan dan juga hasil penelitian-penelitian terdahulu, dapat disimpulkan bahwa media pembelajaran buku digital

Pengembangan Media Pembelajaran Buku Digital Interaktif Berbasis Pendekatan Matematika Realistik untuk Meningkatkan Kemampuan Spasial Siswa 
Vol. 14, No. 2, Desember 2021

interaktif yang dikembangkan dapat meningkatkan kemampuan spasial siswa.

\section{KESIMPULAN}

Berdasarkan hasil analisis dan pembahasan dalam penelitian ini, dikemukakan beberapa kesimpulan sebagai berikut:

1. Validasi media pembelajaran buku digital interaktif yang dikembangkan berada pada kategori "Valid" ditinjau dari analisis hasil validitas media pembelajaran oleh para validator dengan nilai ratarata total sebesar 3,73.

2. Media pembelajaran buku digital interaktif yang dikembangkan memenuhi kriteria kepraktisan media pembelajaran ditinjau dari analisis hasil observasi keterlaksanaan pembelajaran. Skor yang diperoleh pada uji coba I sebesar 2,87 (kategori "Terlaksana dengan Kurang Baik") dan belum memenuhi kriteria keberhasilan penelitian. Namun setelah melakukan beberapa revisi, pada uji coba II skor observasi keterlaksanaan pembelajaran meningkat menjadi 3,73 (kategori "Terlaksana dengan Baik”). Sehingga media pembelajaran yang dikembangkan berhasil memenuhi kriteria kepraktisan media pembelajaran.

3. Media pembelajaran yang dikembangkan telah memenuhi kriteria keefektifan yang ditetapkan. Pada uji coba I ketercapaian kemampuan spasial matematis siswa adalah $40 \%$ (6 siswa) dan pada uji coba II sebesar 86,67\% (13 siswa). Rata-rata persentase pencapaian waktu ideal aktivitas siswa untuk dua pertemuan pada uji coba I adalah $23,61 \%, 26,39 \%, 27,08 \%, 13,19 \%, 6,25 \%$, dan $3,47 \%$. Sedangkan pada uji coba II rata-rata persentase pencapaian waktu ideal aktivitas siswa untuk tiga pertemuan adalah $24,07 \%, 28,70 \%$, $26,39 \%, 11,11 \%, 6,48 \%$, dan 3,24\%. Rata- rata respon siswa pada uji coba I adalah 3,70 (kategori "Tertarik") dan pada uji coba II adalah 3,74 (kategori "Tertarik").

4. Peningkatan kemampuan spasial matematis siswa juga terlihat pada masing- masing indikator kemampuan spasial matematis. Berdasarkan indeks gain ternormalisasi, diperoleh bahwa pada uji coba I terjadi peningkatan nilai dengan kriteria rendah skor $0,20(\mathrm{~N}-$ Gain $\leq 0,3)$ dan pada uji coba II terjadi peningkatan nilai dengan kriteria sedang dengan skor $0,40 \quad(0,3<\mathrm{N}$-Gain $\leq 0,7)$. Sehingga dapat disimpulkan bahwa media pembelajaran buku digital interaktif yang dikembangkan ini dapat meningkatkan kemampuan spasial matematis siswa.

\section{REFERENSI}

Akker, J. V. D. (2007). An Introduction to Educational Design Research. Proceedings of The Seminar Conducted at The East China Normal University, Shanghai (PR China). November 23-26.

Al-Tabany, T. I. B. (2017). Mendesain Model Pembelajaran Inovatif-Progresif dan Kontekstual. Jakarta: Kencana Prenada Group.
Andina, E. (2012). Buku Digital dan Pengaturannya. Aspirasi. 2(1): 79-95.

Anggraini, Y, D. (2020). Pengembangan Media Pembelajaran e-Book Novelmatika untuk Meningkatkan Pemahaman Konsep Statistika. Jurnal Amanah Pendidikan dan Pengajaran, 1(1): 35-48.

Arifin, A. M., \& Pujiastuti, H., Sudiana, R. (2020). Pengembangan Media Pembelajaran STEM dengan Augmented Reality untuk Meningkatkan Kemampuan Spasial Matematis Siswa. Jurnal Riset Pendidikan Matematika, 7(1): 59-73.

Arsyad, A. (2017). Media Pembelajaran. Jakarta: PT Raja Grafindo Persada.

Ashyar, R. (2011). Kreatif Mengembangkan Media Pembelajaran. Jakarta: Gaung Persada (GP) Press Jakarta.

Asih, Y. K. (2018). Kemampuan Visual Spasial Dalam Pemecahan Masalah Geometri Berdasarkan Tahapan Berfikir Van Hieles. Skripsi. Surakarta: Universitas Muhammadiyah Surakarta.

De Lange, J. (1996). Using and Applying Mathematics in Education. Netherlands: Kluwe Academic Publisher.

Freudenthal, H. (1991). Revisitting Mathematics Education. Dordrechr: Reidel Publishing.

Hafizd, M., \& Masriyah. (2020). Pengembangan Media Pembelajaran Berbasis Android untuk Pembelajaran Permutasi dan Kombonasi. Kreano Jurnal Matematika Kreatif-Inovatif, 11(2): 126-135.

Hake, R. R. (1999). Analyzing Change/Gain Scores. Woodland Hilis: Dept. Of Physics, Indiana University.

Hasratuddin. (2018). Mengapa Harus Belajar Matematika. Medan: Perc. Edira.

Herzamzam, D. A., \& Rahmad, I. N. (2020). Penerapan Realistic Mathematics Education (RME) di Sekolah Dasar. Prima Magistra: Jurnal Ilmiah Kependidikan, 1(2): 184-190.

Hidayat, K. N., \& Fiantika, F. R. (2017). Analisis Proses Berfikir Spasial Siswa Pada Materi Geometri Ditinjau Dari Gaya Belajar. Prosiding SI MaNIs (Seminar Nasional Integrasi Matematika dan Nilai Islami) , 1 (1): 385-394.

Istifarida, B., Santoso, S., Yusup, Y. 2017. Development Of E-Book Problem Based LearningGIS To Increase Spatial Thinking Skills In Class X SMA N 1 Sragen 2016/2017. Jurnal Geoeco, 3(2): 133- 144.

Jannah, N., Fadiawati, N., Tania, L. (2017). Pengembangan E-Book Interaktif Berbasis Fenomena Kehidupan Sehari-Hari Tentang Pemisahan Campuran. Jurnal Pendidikan dan Pembelajaran Kimia, 6(1): 186-198.

Lestari, K. E., \& Yudhanegara, M. R. (2015). Penelitian Pendidikan Matematika. Bandung: Refika Aditama.

Maier, P. H. (1998). Spatial Geometry and Spatial Ability - How to Make Solid Geometry Solid? Annual Conference od Didactic of Mathematics 
1996. Osnabrueck: University of Osnanbrueck. 6375.

Marselina, V., \& Muhtadi, A. (2019). Pengembangan Buku Digital Interaktif Matematika pada Materi Geometri. Jurnal Inovasi Teknologi Pendidikan, 6(2): 196-207.

Netriwati \& Lena, M. S. (2017). Media Pembelajaran Matematika. Bandar Lampung: Permata Net.

Priyanto, I. F. \& Sedyaningsih, S. P. (2013). Buku Digital: Kajian Literatur Perkembangan dan Pengaruhnya pada Perpustakaan. FIHRIS, 8(2): 112.

Rosida, Faidawati, N., \& Jalmo, T. (2017). Efektivitas Penggunaan Bahan Ajar E-Book Interaktif dalam Menumbuhkan Keterampilan Berpikir Kritis Siswa. Jurnal Pembelajaran Fisika, 5(1): 2302-0105.

Rozak, A., Darmadi, \& Murtafi'ah, W. (2018). Pengembangan Media Pembelajaran SASA-AURA untuk meningkatkan prestasi peserta didik SMK Cendekia Madiun Tahun Ajaran 2017/2018. Jurnal Pendidikan dan Ilmu Pengetahuan, 18(1): 26140578.

Sadjiman, A. S., Rahardjo, R., Haryono, A., \& Harjito. (2011). Media Pendidikan, Pengertian, Pengembangan, dan Pemanfaatannya. Jakarta: Rajagrafindo Persada.

SEAMOLEC. (2013). Buku Sumber Simulasi Digital Versi September 2013: Upaya Mengkomunikasikan Gagasan atau Konsep Melalui Presentasi Digital. Jakarta: SEAMOLEC.

Setiawan, A. (2017). Belajar dan Pembelajaran. Ponorogo: Uwais Inspirasi Indonesia.

Shoimin, A. (2016). 68 Model Pembelajaran Inovatif dalm Kurikulum 2013. Yogyakarta: Ar-Ruzz Media.

Sinaga, J. A. (2015). Pengembangan Perangkat Pembelajaran Matematika Berorientasi Model Pembelajaran Berdasarkan Masalah untuk Meningkatkan Pemahaman Konsep Siswa SMP. Jurnal Pendidikan Matematika dan Terapan Pendidikan Matematika FKIP - Univ. HKBP Nomensen, 1(3): 29-41.

Sonda, R., Alimuddin, \& Asdar. (2016). Efektifitas Pembelajaran Matematika Realistik (PMR) Setting Kooperatif Tipe NHT pada Materi Kesebangunan Siswa Kelas IX SMP Negeri 1 Simbuang. Jurnal Daya Matematis,4(1): 1-12.

Sumarli, Nugroho, S, N., \& Yulianti, I. (2018). Keefektifan Model Pembelajaran Creative Problem Solving Berpendekatan Inquiry Terhadap Keterampilan Proses Sains Siswa. Physics Communication, 2(1): 63-69.

Surya, E. (2010). Visual Thinking dalam Memaksimalkan Pembelajaran Matematika Siswa dapat Membangun Karakter Bangsa. Jurnal Penelitian Pendidikan, 10(10): 1-7.

Susanti, L., \& Rosyidi, A. H. (2013). Pembelajaran Berbasis Origami Untuk Meningkatkan Visualisasi Spasial dan Kemampuan Geometri Siswa SMP. 2(2): 1-8.
Sutikno, S. (2013). Belajar dan Pembelajaran. Lombok: Hollistica.

Tasmalina, T., \& Prabowo, P. (2018). Pengaruh Media Video Pembelajaran Terhadap Hasil Belajar Siswa Pada Sub Materi Spermatophyta di SMA Swasta Nurul Amaliyah

Utami, C. (2020). Kesalahan Siswa dalam Menyelesaikan Soal Kemampuan Spasial Matematis. Al-Khawarizmi: Jurnal Pendidikan Matematika dan Ilmu Pengetahuan Alam, 8(2): 123-132.

Uygan, C., \& Kurtuluş, A. (2016). Effects of teaching activities via Google Sketchup and concrete models on spatial skills of preservice mathematics teachers. Turkish Journal of Computer and Mathematics Education (TURCOMAT), 7(3): 510-510.

Wiarto, G. (2016). Media Pembelajaran dalam Pendidikan Jasmani. Yogyakarta: Laksitas.

Wibowo, Tri Prayitno. 2014. Pengembangan Bahan Ajar Elektronik Multimedia Book Pada Materi Sistem Organisasi Kehidupan di SMP. Unnes Journal of Biology Education, 3(1).

Wulansari, A. N., \& Adirakasiwi, A. G. (2019). Analisis Kemampuan Spasial Matematis Siswa dalam Menyelesaikan Masalah Matematika. Prosiding Seminar Nasional Matematika dan Pendidikan Matematika Sesiomadika. 504-513.

Yusminar. (2014). E-Book dan Pengguna Perpustakaan Perhuruan Tinggi di Jakarta. Al-Maktabsumarliah, 13(1): 34-39.

Pengembangan Media Pembelajaran Buku Digital Interaktif Berbasis Pendekatan Matematika Realistik untuk Meningkatkan Kemampuan Spasial Siswa 